\title{
DEVELOPING MIND MAPPING MODEL BASED ON PROPHETIC VALUES IN WRITING EXPOSITION TEXT
}

\author{
Neneng Maelasari ${ }^{1}$, Dadang Sunendar ${ }^{2}$, Andoyo Sastromiharjo $^{3}$, Yeti Mulyeti ${ }^{4}$ \\ 1,2,3,4 Universitas Bale Bandung, Bandung, Indonesia \\ Imaelasarineneng@yahoo.com, ${ }^{2}$ dadangsunendar@upi.edu, ${ }^{3}$ andoyosastromiharjo@upi.edu, ${ }^{4}$ yetimulyati@upi.edu
}

\begin{abstract}
This research and development aimed to achieve 2 main objectives: to develop a mind mapping model based on prophetic values in writing exposition texts, and to describe and discuss the profile of mind mapping model based on prophetic values in writing exposition texts. This model was developed by using $4 D$ model (definition, design, development, and dissemination) which was modified to 3DI (definition, design, development, and implementation). This research was conducted in the academic year 2019/2020 at a high school in Bandung. The instruments of this research were questionnaires and observation sheets that fulfilled the validity and reliability requirements. The initial product was tested on a limited trial in $X I P A$ SMA Negeri 1 Baleendah Bandung. Then, the revised product was tested extensively in 2 classes, namely XIPA-3 and X IPS-5. The last procedure in this research was the dissemination of the final product prototype, which was teaching materials entitled Mind Mapping Based on Porphetic Values: Teaching Materials for Writing Exposition Texts for Grade X SMA/MA. This teaching material consisted of 30 pages, A4, time new roman, 12 automatic spaces outside the start page of 7. Ho was rejected for the paired sample t test because the sig. $0.037<p=0.05$ for class X IPA-3 and the sig. $0.037<$ $p=0.05$ for class X IPS-5. Thisproduct was believed to contribute to the process of learning writing exposition texts at high schools. After that, as users, the Indonesian teachers scored in mode 4 for a scale of 1 to 4 for the 4 feasibility indicators. The score mode of 4 also occured in the assessment given by the expert team.
\end{abstract}

Keywords: mind mapping model, prophetic values, exposition text

\section{PENGEMBANGAN MODEL PEMBELAJARAN PETA PIKIRAN BERBASIS NILAI PROFETIK DALAM MENULIS TEKS EKSPOSISI}

\begin{abstract}
ABSTRAK
Penelitian dan pengembangan ini bertujuan untuk mencapai 2 tujuan utama. Pertama, mengembangkan model pembelajaran peta pikiran berbasis nilai profetik dalam menulis teks eksposisi. Kedua, mendeskripsikan dan membahasan profil model pembelajaran peta pikiran berbasis nilai profetik dalam menulis teks eksposisi. Pengembangannya menggunakan model 4D (define, design, develpoment, dissimination) yang dimodifikasi menjadi 3DI yakni definisi, desain, pengembangan, dan implimentasi. Penelitian ini dilakukan pada tahun ajaran 2018/2019 di SMA di Bandung. Digunakan instrumen penelitian berbentuk tes dan nontes yakni kuesioner dan observasi yang memenuhi syarat validitas dan releabilitas. Produk awal diujicobakan secara terbatas pada satu kelas X IPA SMANegeri 1 Baleendah Bandung. Produk revisi diujicobakan secara meluas di 2 SMA yakni di kelas X IPA-3 dan kelas X IPS-5. Prosedur terakhir adalah diseminasi prototype produk akhir yakni bahan ajar yang berjudul Peta Pikiran Berbasis Nilai Profetik: Bahan Ajar Menulis Teks Eksposisi untuk Kelas X SMA/MA. Bahan ajar ini berjumlah 30 halaman, A4, time new roman, 12 spasi automatis di luar halaman awal sebanyak 7. Ho ditolak untuk uji t sampel berpasangan karena nilai sig. $0.037<\mathrm{p}=0.05$ dan untuk kelas X IPA-3 karena sig. $0.000<\mathrm{p}=0.05$ untuk kelas X IPS-5. Produk bahan ajar diyakini memberikan kontribusi bagi pembelajaran menulis teks eksposisi di SMA. Para guru Bahasa Indonesia sebagai pengguna bahan ajar menilai pada modus 4 untuk skala nilai 1 s.d. 4 terhadap 4 indikator kelayakan. Modus nilai 4 juga terjadi pada penilaian yang diberikan oleh tim ahli.
\end{abstract}

Kata Kunci: model peta pikiran, nilai profetik, pembelajaran menulis teks eksposisi

\begin{tabular}{|c|c|c|}
\hline Submitted & Accepted & Published \\
\hline 10 Juni 2021 & 19 Juli 2021 & 29 Juli 2021 \\
\hline
\end{tabular}

\begin{tabular}{|l|c|c|}
\hline Citation & $:$ & $\begin{array}{r}\text { Maelasari, N.,Sunendar, D., Sastromiharjo, A., \& Mulyeti, Y. (2021). Developing a Mind Mapping Model based on } \\
\text { Prophetic Values in Writing Exposition Text. Jurnal PAJAR (Pendidikan dan Pengajaran), 5(4), 1123-1133. DOI } \\
: \text { http://dx.doi.org/10.33578/pjr.v5i4.8437. }\end{array}$ \\
\hline
\end{tabular}

\section{PENDAHULUAN}

Pembelajaran bahasa termasuk dalam golongan pembelajaran kompleks dan rumit. Dikatakan kompleks karena melibatkan semua aspek bahasa dan aspek psikologis. Dikatakan rumit karena harus tunduk dengan sistem dan sifat

arbitrer. Karenanya, kemampuan menulis siswa tergolong relatif rendah (Alwasilah, 2013; Mulyati \& Cahyani, 2015; Ariningsih dkk., 2012; dan Iskandarwassid \& Sunendar, 2008). 
Dalam pembelajaran menulis dalam konteks mengekspresikan gagasan kepada orang lain, kesulitannya terletak kepada kesiapan guru menyiapkan bahan ajar yang objektif, sistematis, kritis, dan motivatif. Apatah lagi jika pembelajaran menulis itu difokuskan kepada teks argumentatif yakni teks eksposisi. Kerumitan itu berbanding lurus dengan kesuksesan belajar yang berpeluang dicapai. Maknanya, jika guru mampu memfasilitasi siswa untuk dapat membentuk teks eksposisi, maka luaran pembelajaran ini bukan saja berguna bagi aspek menulis melainkan juga memperkuat aspek membaca.

Melalui menulis teks eksposisi, siswa akan menambah berbagai informasi dan memperluas wawasan keilmuan (Sarimanah, 2016). Melalui struktur argumentasi, atas dasar tesis, siswa dapat mengidentifikasi potensi dirinya sendiri dalam melakukan pemikiran, melakukan kegiatan melalui daya nalarnya, kemampuan bidang keilmuan dan mengonstruksi ide. Seseorang yang mumpuni dalam menulis eksposisi, juga harus memperbanyak latihan melalui proses belajar mengajar. Membuat teks eksposisi adalah sebuah aktivitas yang berkesinambungan sehingga kegiatan belajar mengajarnya juga dilakukan secara berkelanjutan.

Selaras dengan uraian di atas, dirumuskan masalah penelitian. Rumusan masalah yang dimaksud adalah:

1) Bagaimanakah prosedur pengembangan bahan ajar model peta pikiran berbasis nilai profetik dalam pembelajaran menulis teks eksposisi siswa kelas X SMA?

2) Bagaimanakah profil prototype bahan ajar model peta pikiran berbasis nilai profetik dalam pembelajaran menulis teks eksposisi siswa kelas X SMA?

Pengembangan bahan ajar menggunakan model 4D (define, design, development, dissimination) yang dimodifikasi menjadi 3DI yakni definisi, desain, pengembangan, dan implimentasi (Thiagarajan dalam Sugiyono, 2015). Komponen definisi mencakup aspek: 1) analisis awal-akhir (front-end analysis); 2) analisis siswa (learner analysis); 3) analisis tugas (task analysis); 4) analisis konsep (concept analysis); 5) analisis perumusan indikator pembelajaran (specifying instructional analysis).

Guru mata pelajaran bahasa Indonesia merupakan pihak yang berkompeten dan bertanggung jawab untuk mengembangkan dan melatih keterampilan menulis teks eksposisi. Menggunakan model peta pikiran berbasis nilai profetik merupakan model pembelajaran yang diyakini dapat meningkatkan motivasi siswa dan kemampuan siswa menulis eksposisi. Hal ini disebabkan model peta pikiran berbasis nilai profetik dipandang sebagai pola pembelajaran yang paling sukses dalam membentuk sebuah tatanan kehidupan manusia yang berkualitas.

Secara etimologi, istilah profetik berasal dari bahasa Inggris yakni prophetic. Secara leksikal bermakna kenabian. Dengan kata lain, profetik adalah adopsi dari prophetic. Makna kenabian identik dengan sifat-sifat Nabi Muhammad SAW.

Syihabuddin (2011) mengemukakan bahwa pendekatan profetik memandang peserta didik sebagai manusia yang suci, sehingga dapat dihiasi secara langsung dengan akhlak terpuji. Nilai profetik digunakan dalam usaha untuk menjelaskan atau memahami realitas sosial.

Guru mempertimbangkan tujuh karakteristik pembelajaran profetik yang bisa dilakukan yang diadaptasi dari Mujahid (Maelasari, 2019), yakni:

1) Shidiq (jujur). Guru yang profetik mengutamakan integritas moral (akhlak). Dalam proses pembelajaran dia jujur dalam menggunakan model, pendekatan, strategi, metode, teknik sesuai dengan karakteristik materi pembelajaran.

2) Amanah (dapat dipercaya). Guru yang profetik mengutamakan nilai-nilai tanggung jawab, dapat dipercaya, dapat diandalkan, jaminan keberhasilan profesional dalam melaksanakan tugasnya. Dalam proses pembelajaran, guru dapat dipercaya serta selalu memberi yang terbaik untuk siswanya.

3) Tablig (berkomunikasi). Guru yang profetik berinteraksi dan berkomunikasi dengan efektif, memiliki visi, inspirasi, dan motivasi kepada siswanya untuk belajar. 
4) Fathanah (cerdas). Guru yang profetik memiliki kecerdasan yang majemuk: intelektual, emosional, dan spiritual, memimpin siswa, mampu mengambil hikmah dari pengalaman, percaya diri, cermat, inovatif, dan bermotivasi tinggi terhadap siswanya.

5) Istiqamah (konsisten). Guru yang profetik berprinsip selalu ingin mengubah siswa ke arah yang lebih baik, taat peraturan, tekun disiplin, pantang menyerah, dan bersungguhsungguh.

6) Ijtihad (berpikir). Setiap kasus yang terjadi selama proses pembelajaran dijadikan media baginya untuk berijtihad mencari solusi terbaik dalam membelajarkan siswa. Guru itu tidak melihat masalah dengan kasat mata tetapi dia melihat dengan kaca mata ilmiah, dia seorang peneliti sejati.

7) Muhasabah (introspeksi diri). Guru yang profetik berprinsip menulis sesuatu yang dikerjakan dan mengerjakan sesuatu yang ditulis dalam rangka menjadi bahan untuk introspeksi diri.

Merupakan kendala tersendiri bagi guru untuk mengajarkan menulis teks eksposisi. Kesulitan ini disebabkan guru cenderung menggunakan buku sekolah elektronik (BSE). Buku nasional ini tidak berisi model peta konsep yang berbasis kepada nilai profetik. Itulah sebabnya, penelitian tentang pengembangan model peta pikiran berbasis nilai profetik dalam pembelajaran menulis teks eksposisi di kelas $\mathrm{X}$ SMA/MA/SMK urgen dilakukan. Melalui penelitian dan pengembangan, disusun teks eksposisi bertopik selaras dengan 7 karakteristik nilai profetik sebagaimana sudah diulas di atas.

\section{METODE PENELITIAN}

Penelitian ini menggunakan metode R\&D. Pengembangannya menggunakan model 4D (define, design, development, dissimination) yang dimodifikasi menjadi 3DI yakni definisi, desain, pengembangan, dan implimentasi (Thiagarajan, 1974 dalam Sugiyono, 2015). Penelitian ini dilakukan pada tahun ajaran 2019/2020 di SMA di Bandung. Digunakan instrumen penelitian berbentuk tes dan nontes yakni kuesioner dan pedoman observasi yang memenuhi syarat validitas dan reliabilitas. Produk awal diujicobakan secara terbatas pada satu kelas X IPA SMA Negeri 1 Baleendah Bandung. Produk revisi diujicobakan secara meluas di 2 SMA yakni di kelas X IPA-3 dan kelas X IPS-5. Prosedur terakhir adalah diseminasi prototype produk akhir yakni bahan ajar yang berjudul Model Peta Pikiran Berbasis Nilai Profetik: Bahan Ajar Menulis Teks Eksposisi untuk Kelas X SMA/MA/SMK. Bahan ajar ini berjumlah 30 halaman, A4, time new roman, 12 spasi automatis di luar halaman awal sebanyak 7 .

Setiap teks eksposisi yang ditempatkan pada setiap pembelajaran, terlebih dahulu diukur tingkat keterbacaan. Pengukuran menerapkan prinsip teks kloz. Karenanya, setiap teks ekpsosisi yang berbasis nilai profetik diubah menjadi teks koz. Teks kloz ini pula dikenakan kepada siswa kelas X SMA Negeri di Bandung. Razak (2018) dan Harjasujana \& Mulyati (2010) menyebutkan bahwa teks eksposisi dikatakan berketerbacaan tinggi, jika hasil teks kloz minimal 60,00.

Teks kloz dimbangkan oleh tim ahli sebelum digunakan. Penimbangan menggunakan skala Likert yang disederhanakan yakni skala 1 s.d. 4 (Sudiati \& Nurhidayah, 2017) dan Budiaji (2013). Produk akhir juga ditimbang oleh pengguna dan tim ahli. Penimbangan menggunakan indikator kelayakan isi, penyajian, bahasa, dan grafika (Muslich, 2010).

Data prates dan pascates dikumpulkan menggunakan instrumen tes. Pertama, instrumen tes pilihan ganda untuk tes aspek pengetahuan. Tes ini memenuhi syarat validitas isi karena disusun mengikuti prosedur sehingga menghasilkan kisikisi tes untuk dijadikan dasar penulisan 17 butir tes pilihan ganda. Kedua, instrumen tes esai untuk tes aspek keterampilan. Tes ini juga memenuhi syarat validitas isi karena disusun mengikuti prosedur sehingga menghasilkan kisi-kisi tes untuk dijadikan dasar sehingga menghasilkan 4 butir tes esai.

Data prates dan pascates menulis teks eksposisi dianalisis menggunakan prosedur statistik inferensial. Prosedur yang dimaksud 
adalah uji t sampel berpasangan (Razak, 2020) dan Crocker \& Algina (1986).

\section{HASIL DAN PEMBAHASAN \\ Proses Pengembangan \\ 1. Definisi}

Prosedur definisi meliputi beberapa kegiatan analisis. Jenis analisis selaras dengan teori definisi yang digunakan sebagaimana sudah diuraikan bagian pendahuluan.

Pertama, bahan ajar ini menggunakan sistem pembelajaran induktif yang bermula dari hal yang khusus sehingga berakhir kepada hal yang umum. Di bagian awal bahan ajar disajikan 4 contoh teks eksposisi. Setiap contoh teks eksposisi berbeda jenis topik yakni nilai profetik. Pembelajaran berlanjut kepada latihan dan pengerjaan penulisan teks eksposisi. Bagian akhir pembelajaran dalam bahan ajar ini berisi rangkuman tentang hakikat menulis teks eksposisi.

Kedua, sasaran bahan ajar ini adalah siswa kelas X SMA. Mereka adalah siswa kelas X IPA-1 SMA Negeri 1 Baleendah, Bandung berjumlah 34 siswa pada uji coba terbatas dan siswa kelas X IPA3 dan IPS-5 SMA Negeri 1 Soreang, Bandung pada uji coba skala luas masingmasing berjumlah 34 orang sebagai kelompok populasi.

Ketiga, menetapkan tugas yang harus ada dalam bahan ajar yakni tugas terkait dengan penyusunan teks eksposisi yang berbasis kepada nilai profetik. Tugas yang diwajibkan kepada siswa melalui bahan ajar ditetapkan atas nama Latihan dan Tes Formatif. Latihan berisi pertanyaan tentang pengetahuan teks eksposisi dan pengetahuan tentang kalimat dan paragraf dalam teks eksposisi. Tes formatif sesungguhnya adalah latihan yang isinya adalah latihan menulis paragraf yang berisi 7 karakteristik nilai profetik atas dasar model teks eksposisi yang disajikan di dalam bahan ajar.

Keempat, menetapkan konsep-konsep pembelajaran yang menggunakan model peta pikiran berbasis nilai profetik dalam pembelajaran menulis teks eksposisi. Konsep pengetahuan mencakup pengetahuan tentang: 1) menulis; 2) teks eksposisi; dan 3) kalimat dalam paragraf; 4) kejujuran; 5) amanah; 6) komunikasi; 7) kecerdasan; 8) konsisten; 9) berpikir kritis; 10) introspeksi diri.

Kelima, dari sisi tujuan pembelajaran, bahan ajar ini berisi rumusan indikator. Rumusan ini terikat dengan sepasang KD-3.4 dan KD-4.4. Redaksi-3.4: Menganalisis struktur teks eksposisi. Redaksi KD 4.4: Mengonstruksikan teks eksposisi dengan memerhatikan isi (permasalahan, argumen, pengetahuan, dan rekomendasi), struktur dan kebahasaan. KD-3.4 berindikator: 1) memahami makna teks ekspsosisi; 2) memahamai struktur teks eksposisi; 3) memahami makna tesis dalam struktur teks eksposisi; 4) memahami makna argumentasi dalam teks eksposisi. KD-4.4 berindikator: 1) menulis teks eksposisi dengan topik kejujuran dan amanah; 2) menulis teks eksposisi dengan topik komunikasi dan kecerdasan; 3) menulis teks eksposisi dengan topik konsistensi dan ketajaman berpikir; 4) menulis teks eksposisi dengan topik ketajaman berpikir dan instrospeksi diri.

Tabel 1. Rangkuman Validasi Kelayakan Indikator Bahan Ajar per KD

Indikator per KD dan Bahasa
Penimbang-1

\begin{tabular}{ccc}
\multicolumn{4}{c}{ Penimbang (Skala 1} & s.d. 4$)$ \\
Penimbang-2 & Penimbang-3 & Modus
\end{tabular}

Makna teks eksposisi

Struktur teks eskpsosisi

Makna struktur tesis

Makna struktur argumentasi

Topik kejujuran dan amanah

Topik komunikasi dan kecerdasan

\section{KD-3.4: Aspek Pengetahuan}

$\begin{array}{llll}3 & 4 & 4 & 4 \\ 3 & 3 & 4 & 3 \\ 3 & 4 & 4 & 4 \\ 3 & 3 & 3 & 3 \\ : \text { Aspek } & \text { Keterampilan } & & \\ 3 & 4 & 4 & 4 \\ 3 & 4 & 4 & 4\end{array}$


Jurnal PAJAR (Pendidikan dan Pengajaran)

Volume 5 Nomor 3 April 2021 | ISSN Cetak : 2580 - 8435 | ISSN Online : 2614 - 1337

DOI : http://dx.doi.org/10.33578/pjr.v5i4.8437

Topik konsistensi dan berpikir

Topik berpikir dan introspeksi

Makna Paragraf

Kalimat dan gagasan paragraf

Tesis paragraf deduktif

Tesis paragraf induktif

Argumentasi paragraf deduktif

Argumentasi paragraf induktif

Modus Penimbangan

Tafsiran
3

3

Aspek Bahasa

$4 \quad 4$

43

$4 \quad 4$

$4 \quad 4$

4

4
4

4

4

34

$4 \quad 4$

$4-4$

$4 \quad 4$

$4 \quad 4$
4

4

4

3

4

4

4

4

4
Penimbang-1 menilai pada skala 3 (baik). Dua penimbang lainnya menilai pada skala 4 (sangat baik). Dengan demikian, modus penimbangan bernilai 4 (sangat baik).

\section{Desain Produk}

Prosedur kedua pengembangan model peta pikiran berbasis nilai profetik dalam pembelajaran menulis teks eksposisi adalah menyusun desain produk (Gambar 1). Desain produk berisi: 1) komponen awal yang mencakup judul bahan ajar, kata pengantar, daftar isi, dan petunjuk penggunaan bahan ajar; 2) komponen inti dengan sistematika: a) model teks eksposisi (topik kejujuran dan amanah), b) model teks eksposisi (topik komunikasi dan kecerdasan), c) model teks eksposisi (topik konsisten dan ketajaman berpikir), d) model teks eksposisi (introspeksi diri dan amanah).

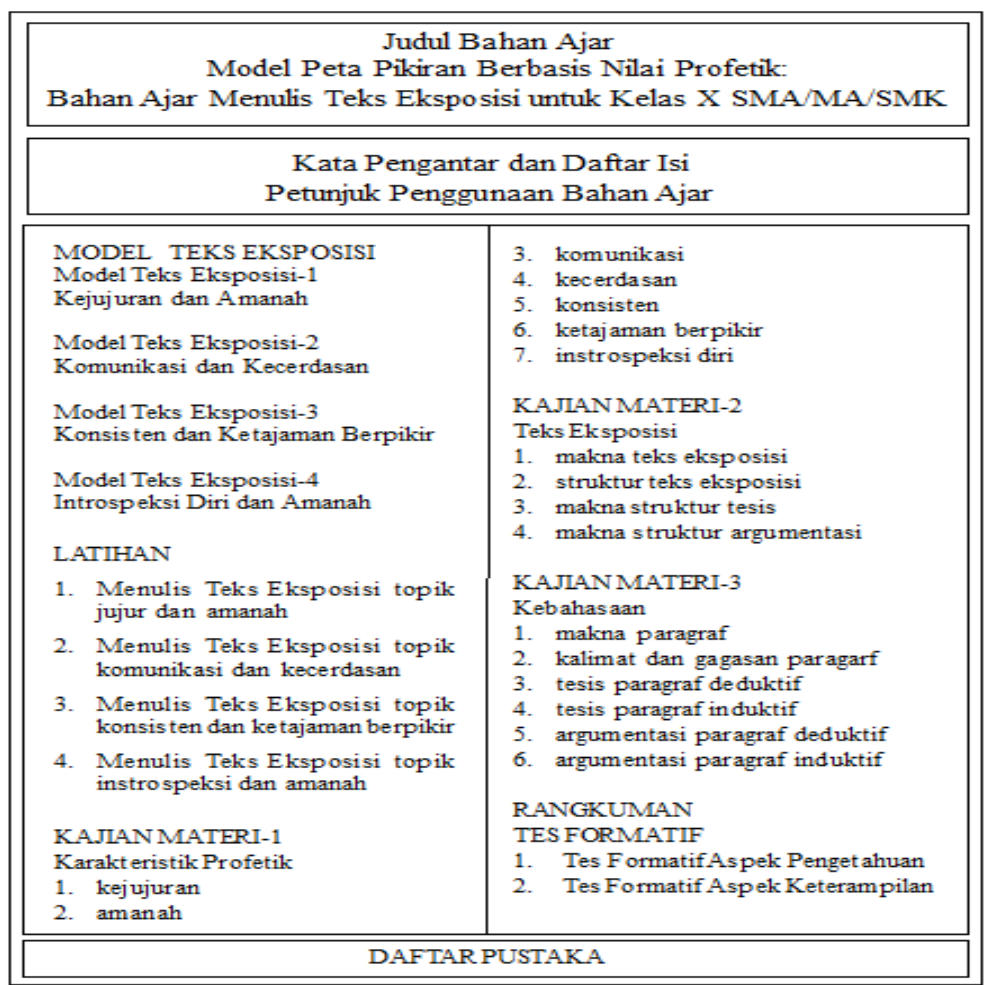

Gambar 1. Desain Bahan Ajar 
Sebagaimana indikator bahan ajar, desain bahan ajar juga dilakukan penimbangan. Jika butir penimbangan bernilai 1 atau 2, maka penimbang yang bersangkutan diminta masukan untuk melakukan revisi agar penilaian minimal pada skala 3. Penimbang-1 menilai pada modus skala 4 (sangat baik). Di antara 4 aspek penimbangan, hanya aspek rangkuman dan tes formatif yang bernilai 3. Penimbang-2 juga menilai pada modus skala 4 (sangat baik). Di antara 4 aspek penimbangan, hanya aspek relevansi kajian materi dengan nilai profetik bernilai 3 (baik). Penimbang3 juga menilai pada modus skala 4 (sangat baik). Di antara 4 aspek penimbangan, hanya aspek relevansi model teks eksposisi dengan nilai profetik bernilai 3 (baik). Dari sisi aspek yang ditimbang, modus penimbangan bernilai 4. Hanya satu aspek yang bernilai 3 (baik). Aspek yang dimaksud adalah aspek relevansi kajian materi dengan nilai profetik.

Tabel 2. Rangkuman Validasi Desain Bahan Ajar

\begin{tabular}{|c|c|c|c|c|}
\hline \multirow[t]{2}{*}{ Aspek Penilaian } & \multicolumn{2}{|c|}{ Penimbang (Skala 1 s.d. 4) } & \multirow[b]{2}{*}{ Penimbang-3 } & \multirow[b]{2}{*}{ Modus } \\
\hline & Penimbang-1 & Penimbang-2 & & \\
\hline $\begin{array}{l}\text { Relevansi model teks eksposisi } \\
\text { dengan nilai profetik }\end{array}$ & 4 & 4 & 3 & 4 (sangat baik) \\
\hline $\begin{array}{l}\text { Relevansi kajian materi } \\
\text { dengan nilai profetik }\end{array}$ & 4 & 3 & 3 & 3 (baik) \\
\hline $\begin{array}{l}\text { Relevansi kajian materi } \\
\text { dengan teks eksposisi }\end{array}$ & 4 & 4 & 4 & 4 (sangat baik) \\
\hline $\begin{array}{l}\text { Relevansi kajian materi } \\
\text { dengan aspek kebahasaan }\end{array}$ & 4 & 4 & 4 & 4 (sangat baik) \\
\hline $\begin{array}{l}\text { Eksistensi rangkuman } \\
\text { dan tes formatif }\end{array}$ & 3 & 4 & 4 & 4 (sangat baik) \\
\hline $\begin{array}{l}\text { Modus Penimbangan } \\
\text { Tafsiran }\end{array}$ & $\begin{array}{l}4 \\
\text { sangat baik }\end{array}$ & $\begin{array}{l}4 \\
\text { sangat baik }\end{array}$ & $\begin{array}{l}4 \\
\text { sangat baik }\end{array}$ & $\begin{array}{l}4 \\
\text { sangat baik }\end{array}$ \\
\hline
\end{tabular}

\section{Pengembangan Produk}

Pengembangan produk awal bahan ajar model peta pikiran berbasis nilai profetik dalam pembelajaran menulis teks eksposisi diawali dengan kegiatan menulis teks eksposisi. Selaras dengan topik sebagai tertera di desain, ditulis 4 teks eskposisi dengan topik yang berbeda-beda berdasarkan nilai profetik. Setiap teks hanya berstruktur tesis dan argumentasi. Teks-1 bertopik jujur dan amanah, 168 kata. Teks-2 bertopik komunikasi dan kecerdasan, 181 kata. Teks-3 bertopik konsisten dan ketajaman berpikir, 174 kata. Teks-4 bertopik instrospeksi diri dan amanah, 153 kata.Untuk memenuhi syarat keterbacaan, semua teks eksposisi diukur melalui tes kloz. Tes kloz ini diteskan kepada 20 siswa kelas X SMA. Hasilnya memperlihatkan bahwa semua tes kloz memiliki skor rata-rata antara 70,97 sampai dengan 75,39. Maknanya, teks eksposisi memiliki keterbacaan tinggi. 
Tabel 3. Rangkuman Rata-rata Hasil Tes Kloz untuk 20 Siswa SMA

$\begin{array}{ccccccc}\text { No. } & \text { Jenis Teks Kloz } & n & \text { item } & \text { mean } & \text { stdev } & \text { Kategori } \\ 1 & \text { Teks Kloz-1 } & 20 & 8 & 71.67 & 2.09 & \text { tinggi } \\ 2 & \text { Teks Kloz-2 } & 20 & 8 & 73.33 & 2.36 & \text { tinggi } \\ 3 & \text { Teks Kloz-3 } & 20 & 8 & 75.39 & 1.98 & \text { tinggi } \\ 4 & \text { Teks Kloz-4 } & 20 & 8 & 70.97 & 2.69 & \text { tinggi }\end{array}$

Selanjutnya semua teks eksposisi dirangkai dalam satuan bahan ajar. Semua teks itu dijadikan model yakni contoh bagi siswa dalam rangka belajar menulis teks eksposisi berbasis nilai profetik. Bagian pertama isi bahan ajar model peta pikiran berbasis nilai profetik secara berturut-turut berisi ( 2 halaman pertama bahan ajar):

1) Model Teks Eksposisi-1 (topik jujur dan amanah): struktur tesis bergaya deduktif; struktur argumentasi bergaya induktif (168 kata).

2) Model Teks Eksposisi-2 (topik komunikasi dan kecerdasan): struktur tesis bergaya induktif; struktur argumentasi bergaya deduktif (181 kata).

3) Model Teks Eksposisi-3 (topik konsisten dan ketajaman berpikir): struktur tesis dan struktur argumentasi bergaya deduktif (174 kata).

4) Model Teks Eksposisi-4 (topik introspeksi diri dan amanah): struktur tesis dan struktur argumentasi bergaya induktif (153 kata).

Urutan ketiga inti bahan ajar struktur latihan. Selaras dengan desainnya, ada 4 jenis latihan menulis teks eksposisi. Setiap jenis teks berbeda karakteristik profetik dan jenis paragraf baik pada struktur tesis maupun struktur argumentasi. Pada dasarnya halaman kosong untuk menulis teks eksposisi (4 halaman A4).

Urutan keempat adalah kajian materi. Struktur ini ditempatkan di bagian akhir bahan ajar karena pendekatan yang digunakan adalah pendekatan induktif. Kajian materi dipilah menjadi: 1) kajian nilai profetik; 2) teks eksposisi; 3) kebahasaan (2 halaman A4).

Urutan kelima adalah rangkuman. Bagian ini berisi narasi tentang rangkuman teks yang bertopik nilai profetik (setengah halaman A4).
Urutan keenam adalah tes formatif. Bagian ini sebenarnya adalah latihan juga. Namun demikian, dia diberi judul tes guna menggerakkan para siswa untuk mengapkannya secara sungguhsungguh. Untuk aspek pengetahuan, tes formatif berbentuk soal pilihan ganda 4 opsi berjumlah 17 item. Untuk aspek keterampilan, tes formatif berbentuk tes unjuk kerja yang tempat menulisnya di lembar bahan ajar itu sendiri berjumlah 4 item. Karenanya, bagian akhir ini pada dasarnya adalah LKPD (8 halaman A4).

Urutan terakhir adalah daftar pustaka. Sitasi ini hanya setengah halaman yang terdiri dari buku dan artikel tentang

1. teks eksposisi;

2. model peta pikiran dan nilai profetik;

3. pengetahuan dan keterampilan menulis.

\section{Implementasi}

\section{Uji Coba Terbatas}

Implementasi merupakan uji coba produk awal. Uji coba terbatas dilakukan pada kelas IPA3 SMA Negeri 1 Baleendah, Bandung pada semester ganjil 2019/2020 minggu keempat Juli. Uji ini memanfaatkan satu kali pertemuan tatap muka 4 x 45 menit. Uji coba ini didahului dengan kegiatan prates aspek pengetahuan yakni 17 soal pilihan ganda (17 menit); memanfaatkan lembar tes formatif di dalam bahan ajar tetapi menggunakan lembaran jawaban tersendiri. Di akhir pertemuan dilakukan postes (17 menit) dengan jumlah soal aspek pengetahuan yang sama.

Kegiatan guru dan siswa dalam pembelajaran uji coba terbatas berjalan sesuai dengan RPP yang mengacu kepada bahan ajar produk awal. Untuk kegiatan inti, para siswa difasilitasi guru mencermati model-model teks eksposisi. Mereka difasilitasi juga untuk dapat 
menemukan persamaan dan perbedaan di antara teks-teks model di dalam halaman 1 s.d. 2 bahan ajar produk awal. Kegiatan ini menghabiskan waktu selama 25 menit untuk mengaktifkan seluruh siswa.

Kegiatan inti siswa di bagian kedua dalam pembelajaran uji coba terbatas ini adalah berlatih menulis teks eksposisi di lembar bahan ajar yakni di halaman 3 s.d. 6. Kegiatan kelompok ini difasilitasi oleh guru untuk memilih satu kelompok nilai profetik dalam teks eksposisi dengan cara menghubungkan dengan bagian awal bahan ajar yakni model teks eksposisi dan bagian kajian materi baik nilai karakteristik, teks eksposisi, maupun kajian kebahasaan. Kegiatan ini menghabiskan waktu selama 30 menit. Beberapa siswa mengalami kesulitan memahami materi kajian tentang profetik untuk nilai instrosepeksi diri aspek kebahasaan tentang kalimat pokok dan kalimat pendukung dalam paragraf. Rangkuman hasil prates dan pascates untuk 32 anggota sampel tertera di dalam tabel berikut.

Tabel 4. Rangkuman Hasil Prates dan Pascates Uji Coba Skala Terbatas Produk Awal

\begin{tabular}{|c|c|c|c|c|c|c|c|c|}
\hline No. & Jenis Tes & $\mathrm{n}$ & mean & stdev & Persen & Kategori & Paired t Test & Ho \\
\hline & Prates & 32 & 9.93 & 2.81 & 58.41 & rendah & & \\
\hline 2 & Pascates & 32 & 11.78 & 1.69 & 69.79 & sedang & sig. $0.031<0.05$ & ditolak \\
\hline
\end{tabular}

Secara kuantitatif, hasil uji coba produk awal memperlihatkan bahwa hasil prates berbeda dengan hasil pascates. Hal ini ditunjukkan oleh angka sig. $0.031<p=0.05$. Karenanya, diyakini produk awal bahan ajar yang dipakai dalam uji coba terbatas pembelajaran berkontribusi kepada hasil belajar menulis teks eksposisi untuk aspek pengetahuan.

\section{Revisi Produk Awal dan Uji Coba Luas}

Mengacu kepada pedoman observasi yang dilakukan oleh observer dan menurut peneliti sebagai guru dalam uji coba terbatas, dilakukan revisi produk awal bahan ajar. Revisi hanya pada aspek kajian materi. Revisi ini dilakukan karena menambah uraian tentang kajian profetik dan kajian kebahasaan. Oleh karena itu, produk revisi berubah yakni bertambah menjadi 19 halaman.

Uji coba luas dilakukan pada 2 kelas yakni IPA-5 dan IPS-3 SMA Negeri 1 Soreang, Bandung pada semester ganjil 2019/2020 minggu kedua Agustus. Uji ini memanfaatkan 2 kali pertemuan tatap muka yakni $2 \times 2 \times 45$ menit. Uji coba ini didahului dengan kegiatan prates aspek pengetahuan yakni 17 soal pilihan ganda (17 menit); memanfaatkan lembar tes formatif di dalam bahan ajar tetapi menggunakan lembaran jawaban tersendiri. Di akhir pertemuan kedua dilakukan pascates dengan jumlah soal aspek pengetahuan yang sama tetapi aspek keterampilan dilakukan dengan sistem take home examination.

Terhadap 64 siswa kelas X IPA-5 dan IPS3 beroleh mean 8.67 (51.00 persen) untuk prates dan 11.28 (66.35 persen) untuk pascates aspek pengetahuan. Melalui analisis SPSS, ternyata sig. $0.016<0.05$ yang bermakna hasil prates dan pascates tidak homogen. Maknanya, nilai pascates lebih baik daripada nilai prates karena nilai pascates lebih tinggi daripada nilai prates. Untuk aspek keterampilan, mean prates sebesar 41.47 persen sedangkan mean pascates sebesar 72.28 persen. Melalui aplikasi SPSS, nilai sig. $0.000<$ $\mathrm{p}=0.05$. Karenanya, Ho ditolak yang bermakna nilai pascates berbeda secara signifikan dengan nilai pascates. Diketahui nilai pascates lebih tinggi dibandingkan dengan nilai prates, maka nilai pascates lebih baik dibandingkan dengan nilai prates dalam pembelajaran menulis teks eksposisi berbahan ajar model peta pikiran berbasis nilai profetik. Rangkuman hasil prates dan pascates tertera di dalam tabel berikut. 
Jurnal PAJAR (Pendidikan dan Pengajaran)

Volume 5 Nomor 3 April 2021 | ISSN Cetak : 2580 - 8435 | ISSN Online : 2614 - 1337

DOI : http://dx.doi.org/10.33578/pjr.v5i4.8437

Tabel 5. Rangkuman Hasil Prates dan Pascates Uji Coba Skala Luas Produk Revisi

\begin{tabular}{|c|c|c|c|c|c|c|c|c|}
\hline No & Jenis Tes per Aspek & $\mathrm{n}$ & mean & stdev & Persen & Kategori & Paired t Test & Ho \\
\hline & Aspek Pengetahuan & & & & & & & \\
\hline 1 & Prates & 64 & 8.67 & 2.97 & 51.00 & rendah & & \\
\hline 2 & $\begin{array}{l}\text { Pascates } \\
\text { Aspek Keterampilan }\end{array}$ & 64 & 11.28 & 2.06 & 66.35 & sedang & sig. $0.016<0.05$ & ditolak \\
\hline 3 & Prates & 64 & 41.47 & 3.11 & 41.47 & rendah & & \\
\hline 4 & Pascates & 64 & 72.28 & 2.67 & 72.28 & sedang & sig. $0.000<0.05$ & ditolal \\
\hline
\end{tabular}

\section{Produk Akhir}

Prosedur terakhir adalah menghadirkan produk akhir. Produk akhir adalah hasil evaluasi dan revisi produk awal. Produk akhir ini disebut dengan istilah prototype. Prototype ini sifatnya sangat terbatas karena tidak sampai kepada prosedur diseminasi kepada pihak pengguna yakni kelompok guru yang lebih luas.

\section{Hasil: Profil Produk Akhir}

Profil produk akhir bahan ajar disajikan dan dianalisis dari beberapa sisi. Pertama, dari fisik bahan ajar. Kedua, dari sisi nonfisik yakni persepsi kelompok guru Bahasa Indonesia dan vakiditas tim ahli tentang produk bahan ajar.

Profil produk akhir secara fisik sangat sederhana. Dia diketik di kertas A4 70 gsm mulai dari sampul sampai dengan akhir menggukan kertas yang sama. Dia dijilid secara simpel yakni hanya dengan dihekter di sisi kiri bagian atas dan bagian bawah setebal 21 halaman. Bagian awal bahan ajar adalah (4 halaman): a) halaman sampul; bertuliskan judul Model Peta Pikiran Berbasis Nilai Profetik: Bahan Ajar Menulis Teks Eksposisi untuk Kelas X SMA/MA/SMK, b) halaman kata pengantar, halaman daftar isi, dan halaman petunjuk penggunaan.

Bagian isi memuat 6 aspek. Aspek itu: 1) 4 halaman tentang model teks eksposisi berbasis nilai profetik; 2) 8 halaman latihan yakni bidang kosong untuk tempat berlatihan menulis teks eksposisi bertopik nilai profetik; 3) 1 halaman kajian materi tentang nilai profetik; 4) 1 halaman kajian materi tentang teks eksposisi; 5) 2 halaman kajian materi tentang kebahasaan; 6) 5 halaman tentang rangkuman, tes fomatif, dan daftar pustaka.

Guru SMA/MA/SMK diminta untuk memberikan tanggapan tentang kelayakan bahan ajar. Rangkuman tanggapan guru termuat di dalam tabel berikut ini.

Tabel 6. Rangkuman Persepsi Guru SMA tentang Kelayakan Bahan Ajar

\begin{tabular}{lllllll} 
No. & Kode Pengguna & Isi & Sajian & Bahasa & Grafika & Modus \\
\hline 1 & Pengguna-1 & 3 & 3 & 4 & 3 & 3 \\
2 & Pengguna-2 & 4 & 4 & 4 & 3 & 4 \\
3 & Pengguna-3 & 4 & 4 & 4 & 3 & 4 \\
4 & Pengguna-4 & 4 & 4 & 4 & 3 & 4 \\
5 & Pengguna-5 & 4 & 4 & 4 & 3 & 4 \\
& Modus Penimbang & 4 & 4 & 4 & 3 & 4 \\
& Tafsiran Penimbangan & sangat & sangat & sangat & baik & sangat \\
& & & baik & baik & baik & baik
\end{tabular}


Persepsi guru SMA/MA/SMK terhadap kelayakan bahan ajar berada pada nilai 4 (sangatbaik). Hanya Pengguna-1 yang memberi nilai pada modus 3 (baik). Dari sisi indikator grafika, semua pengguna menilai pada skala 3 (baik).

Tabel 7 Rangkuman Validasi Tim Ahli tentang Kelayakan Bahan Ajar

\begin{tabular}{|c|c|c|c|c|c|c|}
\hline \multirow[b]{2}{*}{ No. } & \multirow[b]{2}{*}{ Kode Penimbang } & \multicolumn{4}{|c|}{ Kelayakan (Skala Nilai 1-4) } & \multirow[b]{2}{*}{ Modus } \\
\hline & & Isi & Sajian & Bahasa & Grafika & \\
\hline 1 & Penimbang-1 & 4 & 4 & 4 & 3 & 4 \\
\hline 2 & Penimbang-2 & 4 & 4 & 4 & 3 & 4 \\
\hline 3 & Penimbang-3 & 4 & 4 & 4 & 3 & 4 \\
\hline 4 & Penimbang-4 & 4 & 4 & 4 & 3 & 4 \\
\hline 5 & Penimbang-5 & 4 & 4 & 4 & 3 & 4 \\
\hline & $\begin{array}{l}\text { Modus Penimbang } \\
\text { Tafsiran Penimbangan }\end{array}$ & $\begin{array}{l}4 \\
\text { sangat }\end{array}$ & $\begin{array}{l}4 \\
\text { sangat }\end{array}$ & $\begin{array}{l}4 \\
\text { sangat } \\
\text { baik }\end{array}$ & $\begin{array}{l}3 \\
\text { baik } \\
\text { baik }\end{array}$ & $\begin{array}{l}4 \\
\text { sangat } \\
\text { baik }\end{array}$ \\
\hline
\end{tabular}

baik

Modus penimbang adalah 4 (sangat baik). Untuk semua indikator kelayakan bernilai pada skala 4 (sangat baik), kecuali untuk kelayakan grafika bernilai 3 (baik).

\section{Pembahasan}

Pertama, bahan ajar ini memiliki cakupan sangat terbatas yakni khusus KD-3.4 dan KD-4.4. Aspek bahasanya hanya aspek menulis. Jenis teks juga terbatas kepada teks eksposisi. Inilah kelemahan bahan ajar ini. Namun demikian, dari sisi ini, bahan ajar ini dapat dikatakan unggul karena topik eksposisi yang harus ditulis dalam pembelajaran dirinci menurut 7 nilai profetik yang diyakini berintegrasi dengan pembelajaran Pendidikan Agama Islam terutama untuk bidang akhlak dan sejarah kebudayaan Islam (SKI).

Bahan ajar ini lebih baik digunakan pada 2 kali pertemuan. Pertemuan pertama identik sebagai pertemuan reguler, 2 x 45 menit. Menjelang pertmuan hari berikutnya, siswa mengerjakan unitunit latihan menulis secara mandiri dalam skema PR. Dengan demikian, pembelajaran di hari kedua yakni 2 x 45 menit identik sebagai pembelajaran repetisi. Kondisi ini relatif tidak terjadi di
SMA/MA/SMK karena fakra lapangan memperlihatkan bahwa 4 x 45 menit dijadikan satu kali pertemuan. Padahal membagi 2 satuan waktu itu jauh lebih bermakna karena ada jeda yang relatif lama untuk siswa menyelesaikan tugastugas menulis.

\section{SIMPULAN DAN REKOMENDASI}

Pertama, pengembangan model peta pikiran berbasis nilai profetik dalam pembelajaran menulis teks eksposisi: 1) definisi; 2) penyusunan desain produk; 3) pengembangan produk; 4) implementasi yang mencakup: uji coba skala terbatas, uji coba skala luas, dan reproduksi prototype.

Kedua, profil prototype bahan ajar, mencakup: 1) judulnya Model Peta Pikiran Berbasis Nilai Profetik: Bahan Ajar Menulis Teks Eksposisi untuk Kelas X SMA/MA/SMK; 2) tebal 21 halaman diketik di kertas A4, times new roman, size 12 , spasi automatis, margin $2-2 \& 3-3$; 3) halaman awal yakni kata pengantar, daftar isi, dan petunjuk penggunaan.

Terdapat 4 rekomendasi yang dapat penulis sampaikan. Pertama, bagi guru kelas $\mathrm{X}$ 
SMA/MA/SMK semua peminatan hendaknya dapat menggunakan bahan ajar ini untuk mengatasi kelayakan isi dalam bahan ajar BSE terkhusus di SMA tempat uji coba. Kedua, diharapkan prototype terbatas ini berlanjut kepada upaya diseminasi di tingkat MGMP Bahasa Indonesia SMP/SMK/MA. Ketiga, bagi pengawas sekolah, bahan ajar ini dapat dijadikan materi supervisi klinis di kelas $\mathrm{X}$ dalam aspek pembelajaran menulis teks eksposisi. Keempat, secara akademis prototype produk ini sudah dijadikan file pdf dan mudah diakses oleh golongan mahasiswa Prodi Pendidikan Bahasa dan Sastra Indonesia secara dalam konteks mereka mengikuti mata kuliah yang relevan.

\section{DAFTAR PUSTAKA}

Alwasilah, A. Chaedar \& Sonny S. A. (2013). Pokoknya Menulis: Cara Baru Menulis dengan Metode Kolaborasi. Bandung: Kiblat.

Ariningsih, Nur Endah. dkk. (2012). Analisis Kesalahan Berbahasa Indonesia dalam Karangan Eksposisi Siswa Sekolah Menengah Atas. Basastra Jurnal Penelitian Bahasa, Sastra Indonesia dan Pengajarannya. Volume 1, Nonor 1, Desember 2012, 40-53.

Borg, W .R. \& Gall, M. D. (1989). Educational Research: An Introduction. New York: Longman.

Budiaji, W. (2013). Skala Pengukuran dan Jumlah Responden Skala Likert. Jurnal Ilmu Pertanian dan Perikanan, 2(2), 127-133.

Crocker, L. \& Algina, J. (1986). Introduction in Classical and Modern Test Theory. New York: Rinehart and Winston.

Dick, W. dkk. (2014). The Systematic Design of Instruction. Seventh Edition. New Jersey, USA: Pearson.

Iskandarwassid \& Sunendar. (2008). Strategi Pembelajaran Bahasa. Bandung: Rosdakarya.

Maelasari, N. dkk. (2019). Model Pembelajaran Mind Mapping berbasis Nilai Profetik bagi Peningkatan Kemampuan Menulis Eksposisi Siswa Kelas X SMAN I
Baleendah Bandung'. Makalah. Bandung: Riksa Bahasa UPI XIII.

Muslich, M. (2010). Text Book Writing: DasarDasar Pemahaman, Penulisan, dan Pemakaian Buku Teks. Jakarta: Ar-Ruzz Media.

Mulyati, Y. \& Chayani, I. (2015). Keterampilan Berbahasa Indonesia SD: Buku Materi Pokok, PDGK4101/3SKS/1-9, Edisi II. Jakarta: Universitas Terbuka.

Razak, A. (2018). Membaca Pemahaman: Teori dan Aplikasi Pengajaran. Edisi Ketujuh. Pekanbaru: Ababil Press.

Razak, A. (2020). Statistika: Pengolahan Data Sosial Sistem Manual Cetakaan VIII, Edisi Ketujuh. Pekanbaru: Ababil Press.

Sarimanah, E. (2016). Efectivenes of PQ4R Metacognitive Strategy based Reading Learning Models in Junior High School. IJLECR International Journal of Language Education and Culture Review, 2(1), 74-81.

Syihabuddin. (2011). Pendidikan dan Bahasa dalam Perspektif Islam. Bandung: Rizqi.

Sudiati \& Nurhidayah. (2017). Pengembangan Bahan Ajar Membaca Pemahaman Berdasarkan Strategi PLAN (Predict, Locate, Add, Note) untuk Kelas VII. Jurnal LITERA: Jurnal Penelitian Bahasa, Sastra, dan Pengajarannya, 16(1),114128.

Sugiyono. (2015). Metode Penelitian Kuantitatif, Kualitatif, dan Kombinasi (Mixed Methods). Bandung: Alfabeta. 